University of Nebraska - Lincoln

DigitalCommons@University of Nebraska - Lincoln

Faculty Publications: Department of Entomology

Entomology, Department of

2005

\title{
Only large amounts of powdered sugar applied directly to brood cells harms immature honey bees
}

\author{
Nicholas P. Aliano \\ University of Nebraska-Lincoln, naliano@unlserve.unl.edu \\ Marion D. Ellis \\ University of Nebraska-Lincoln, mellis3@unl.edu
}

Follow this and additional works at: https://digitalcommons.unl.edu/entomologyfacpub

Part of the Entomology Commons

Aliano, Nicholas P. and Ellis, Marion D., "Only large amounts of powdered sugar applied directly to brood cells harms immature honey bees" (2005). Faculty Publications: Department of Entomology. 179. https://digitalcommons.unl.edu/entomologyfacpub/179

This Article is brought to you for free and open access by the Entomology, Department of at DigitalCommons@University of Nebraska - Lincoln. It has been accepted for inclusion in Faculty Publications: Department of Entomology by an authorized administrator of DigitalCommons@University of Nebraska - Lincoln. 


\title{
Only large amounts of powdered sugar applied directly to brood cells harms immature honey bees
}

\author{
Nicholas P Aliano* and Marion D Ellis \\ University of Nebraska-Lincoln, Institute of Agriculture and Natural Resources, Department of Entomology, Lincoln, NE 68583, \\ USA
}

Received 1 August 2004, accepted subject to revision 29 October 2004, accepted for publication 22 February 2005

\section{SUMMARY}

We applied measured amounts of powdered sugar directly to honey bee brood combs containing eggs and larvae of known age groups. $24 \mathrm{~h}$ later, we compared powdered sugar-treated brood with similarly aged cohorts of immature bees that did not receive powdered sugar. Low and high doses of powdered sugar ( 0.3 and $0.6 \mathrm{~g}$ per $151.5 \pm 1.0$ cells, respectively) caused significant egg removal of $62.2 \pm 5.1 \%$ and $86.1 \pm 5.1 \%$, respectively, when compared to eggs that received no powdered sugar $(t=16.91 ; \mathrm{df}=29 ; P=0.0001)$. Powdered sugar had no effect on 5-day-old honey bee larvae $(t=0.74 ; \mathrm{df}=29 ; P=0.4668)$, but caused a significant percentage of 8 -day-old larvae $(18.5 \pm 4.5 \%)$ to be removed when applied at the high dose $(t=4.10$; $\mathrm{df}=29 ; P=0.0003$.

Keywords: Apis mellifera, honey bees, Varroa destructor, mites, parasites, control methods, powdered sugar, dust, brood

\section{INTRODUCTION}

We recently developed a technique to remove varroa mites (Varroa destructor) from adult honey bees (Apis mellifera) using powdered sugar. Our technique requires isolating a colony's adult bee population in a detachable box prior to powdered sugar application. We designed a detachable 'bee-box' that connects to the colony's entrance and is capable of holding the adult bee population. By applying a bee repellent, Bee $\mathrm{Go}^{\circledR}$, to a colony, we forced adult bees into the bee-box where they were subsequently dusted with $225 \mathrm{~g}$ of powdered sugar. Adult honey bee populations treated in this manner dropped $76.7 \pm 3.6 \%(n=$ 28) of their mites (Aliano \& Ellis, 2004). This technique does not result in a noticeable amount of powdered sugar in brood cells. Fakhimzadeh (2000) also reported that powdered sugar significantly accelerated mite fall when applied directly to honey bee colonies. Powdered sugar is harmless to adult bees (Fakhimzadeh, 2001) and does not pose a risk of contaminating honey or beeswax because it is a food substance. However, direct application to colonies carries greater risk of introducing powdered sugar into brood cells.

Beekeepers also have used powdered sugar as a carrier for oxytetracycline (OTC) for the control of American foulbrood in honey bee colonies for over 50 years (Shimanuki \& Knox, 1994). Beekeepers apply the antibiotic dust to the top bars of frames containing brood, and it is distributed throughout the colony by trophallaxis. Pettis et al. (2004) reported that powdered confectioners sugar mixed with OTC at concentrations used in the hive (200 $\mathrm{mg}$ in $20 \mathrm{~g}$ sugar) caused significant larval mortality (80\%) when applied directly to brood. They also found that powdered sugar did not cause significant larval mortality when administered without OTC. Their study assessed the impact of powdered sugar on a mixed age group of honey bee brood (instars one to five collectively), and egg mortality was not considered.

With the exception of the study conducted by Pettis et al. (2004), data documenting the effects of powdered sugar to honey bee brood is limited. Powdered sugar inevitably enters brood cells when treating for American foulbrood and when dusting adult bees for varroa control. Our research objective was to assess the impact of powdered sugar falling into three age groups of brood: 2, 5 and 8 days after oviposition.

\section{MATERIALS AND METHODS}

\section{Experimental design}

We conducted our experiment at the University of NebraskaLincoln's Agricultural Research and Development Center in July 2003. Our experimental design was a randomized complete block design. We randomly chose five experimental colonies from a 14 colony apiary. Each of the five colonies represented a block, and each block was subjected to all 9 treatments. We considered two factors, each with three levels: (1) age of immature bees (2, 5 and 8 days after oviposition), and (2) amount of powdered sugar applied (none, $0.3 \mathrm{~g}$, and $0.6 \mathrm{~g}$ per $151.5 \pm 1.0$ cells). Each of the nine treatments had five replications (one rep/block) for a total of 45 observations. However, a single queen escaped her cage in one experimental colony. For this reason, we only had four replications for all egg treatments, and thus 42 observations instead of 45 . Both 5- and 8-day-old treatments were replicated five times. All experimental colonies were headed by Italian queens obtained from Koehnen \& Sons, Inc., Glenn, CA.

\section{Preparing brood frames}

We prepared brood frames by caging queens on empty, drawn worker combs. The cages were made from 8-mesh wire and plastic queen excluder. The cages confined queens to one side of a comb while providing worker bees free access. We located and caged the queens from the five experimental colonies. The frame containing the caged queen was dated and returned to its colony. Queens filled all the available cells with eggs in 24 hours. These frames were then marked with the date and time, and the queen was transferred to another empty frame within the same 


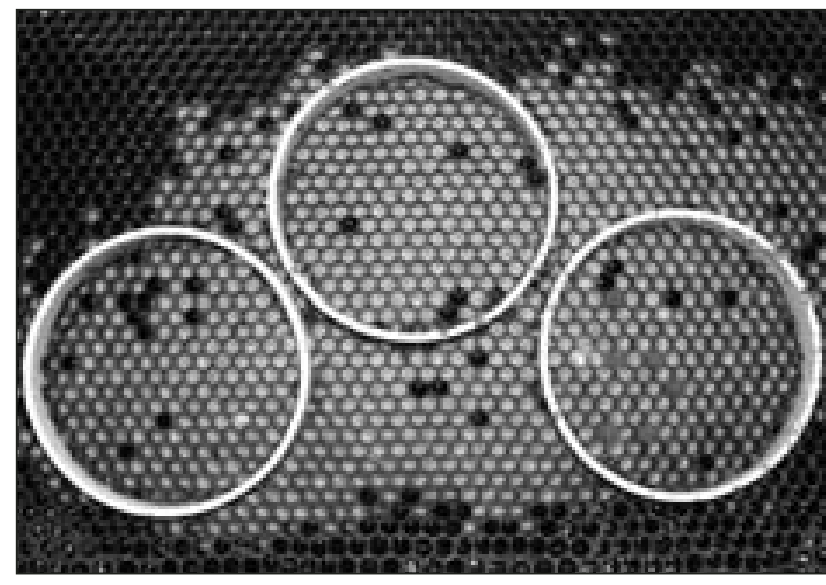

FIG. 1. Eight-day-old larvae encircled by three inch diameter PVC rings prior to dusting. Each ring contained $151.5 \pm 1.0$ larvae, and received one of the three powdered sugar doses (none, $0.3 \mathrm{~g}$, or $0.6 \mathrm{~g}$ ).

colony and caged. We prepared three age groups of brood for each of the five experimental colonies: 2, 5 and 8 days old. The maximum age variance among eggs was 24 hours.

\section{Dusting brood with powdered sugar}

We cut 7.62-cm (3 inch) diameter PVC pipe into 1.91-cm (3/4 inch) rings for dusting arenas. Each ring constituted an experimental unit. We inserted three PVC rings into each frame of brood, and randomly assigned one of three possible treatments to each ring (fig. 1). The three treatments we evaluated were no sugar (control), $0.3 \mathrm{~g}$ and $0.6 \mathrm{~g}$ of powdered sugar (Crystal, Minneapolis, MN). After labelling each ring with its treatment designation, powdered sugar was applied with a $1.91 \mathrm{~cm}$ diameter flour sifter. Figure 2 illustrates a ring of eggs after dusting with powdered sugar.

\section{Counting eggs and larvae}

We counted the number of eggs or larvae in each ring prior to dusting with powdered sugar. On average, there were $151.5 \pm$ 1.0 intact cells $(n=28)$ within each ring. We did not count peripheral cells that were damaged by pressing the pipe into the comb. We returned the dusted frames to their respective colonies and counted the number of eggs or larvae remaining twenty four hours later. We calculated the percentage reduction in the number of eggs or larvae for each ring, and used percentage reduction as our response variable.

\section{Data analysis}

Data were analysed using the PROC MIXED procedure of the SAS program (SAS Institute, 1999). Means were separated using a paired $t$ test $(\alpha=0.05)$.

\section{RESULTS}

There was a significant day $\times$ dose interaction $(F=44.06$; $\mathrm{df}=$ $4,29 ; P<0.0001)$, and therefore, we are reporting simple effects. The nine treatment means for the effect of day $x$ dose are shown in figure 3.

\section{Powdered sugar caused significant removal of eggs}

Eggs (day 2 treatment) were the age group most affected by powdered sugar. Low and high doses of powdered sugar caused significant egg removal $(62.2 \pm 5.1 \%$ and $86.1 \pm 5.1 \%$, respectively) when compared to control eggs ( $t=16.91$; $\mathrm{df}=29 ; \mathrm{P}=$ $0.0001)$. The high dose $(0.6 \mathrm{~g})$ of powdered sugar significantly increased egg removal $(23.8 \pm 5.1 \%)$ when compared to the low dose $(0.3 \mathrm{~g})(t=4.70 ; \mathrm{df}=29 ; P=0.0001)$ (fig. 3$)$.
Powdered sugar caused significant removal of 8-dayold larvae

Powdered sugar caused a significant percentage of 8-day-old larvae $(18.5 \pm 4.5 \%)$ to be removed when applied at the high dose $(t=4.10 ; \mathrm{df}=29 ; P=0.0003)$ (fig. 3). Again, the high dose $(0.6$ $g)$ of powdered sugar significantly increased removal of larvae $(9.7 \pm 4.5 \%)$ when compared to the low dose $(0.3 \mathrm{~g})(t=2.14$; $\mathrm{df}=29 ; P=0.0405)$.

Dusting brood cells with 5-day-old larvae did not result in significant brood removal ( $t=0.74 ; \mathrm{df}=29 ; P=0.4668$ ) (fig. 3). Remaining 5- and 8-day-old larvae pupated and emerged as adults for both doses of powdered sugar.

\section{DISCUSSION}

Our varroa control technique requires isolating a colony's adult bee population in a detachable box prior to powdered sugar application (Aliano \& Ellis, 2004). After dusting, the bees are allowed to groom themselves for $30 \mathrm{~min}$. The bees are able to remove the majority of powdered sugar from their bodies during this time and are then returned to their colony. The small amount sugar remaining on the bees is barely noticeable.

The two quantities of powdered sugar $(0.3 \mathrm{~g}$ and $0.6 \mathrm{~g}$ per 152 cells) that we evaluated in this experiment are much higher than the amount of powdered sugar that would enter brood cells when a colony is dusted using our technique. We tested such high doses of powdered sugar because our initial goal was to determine if large amounts of powdered sugar would negatively impact brood. If large amounts of powdered sugar did not injure brood, more detailed testing of small quantities was not warranted. Specifically, we chose our high dose as $0.6 \mathrm{~g}$ per 152 brood cells, because this was the maximum amount of sugar that could remain in dusted brood cells when a frame was replaced vertically in the hive. It therefore presumably represents the maximum sugar dose that beekeepers might apply when treating for American foulbrood or varroa. Further, some reports (Hayes, 2004) indicate that a number of beekeepers are applying large amounts of powdered sugar directly to colonies for Varroa control. Our observations (unpublished) suggest that this technique is not effective and that it introduces sugar into brood cells.

Even at the highest concentration tested, powdered sugar did not result in significant removal of 5-day-old larvae. We found

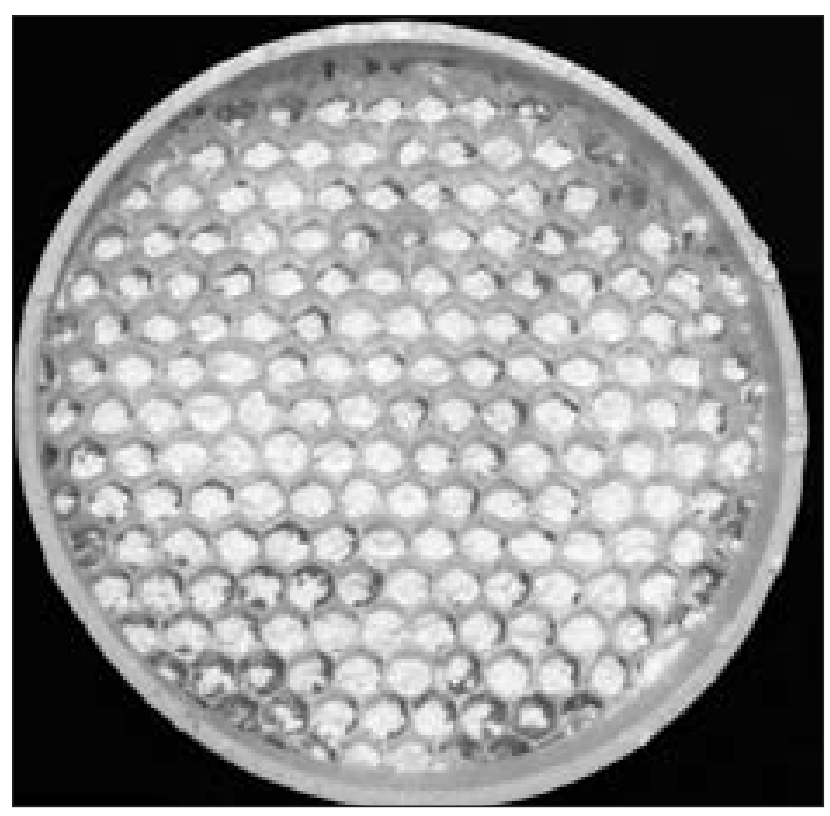

FIG. 2. Ring of eggs after dusting with 0.6 grams of powdered sugar. 


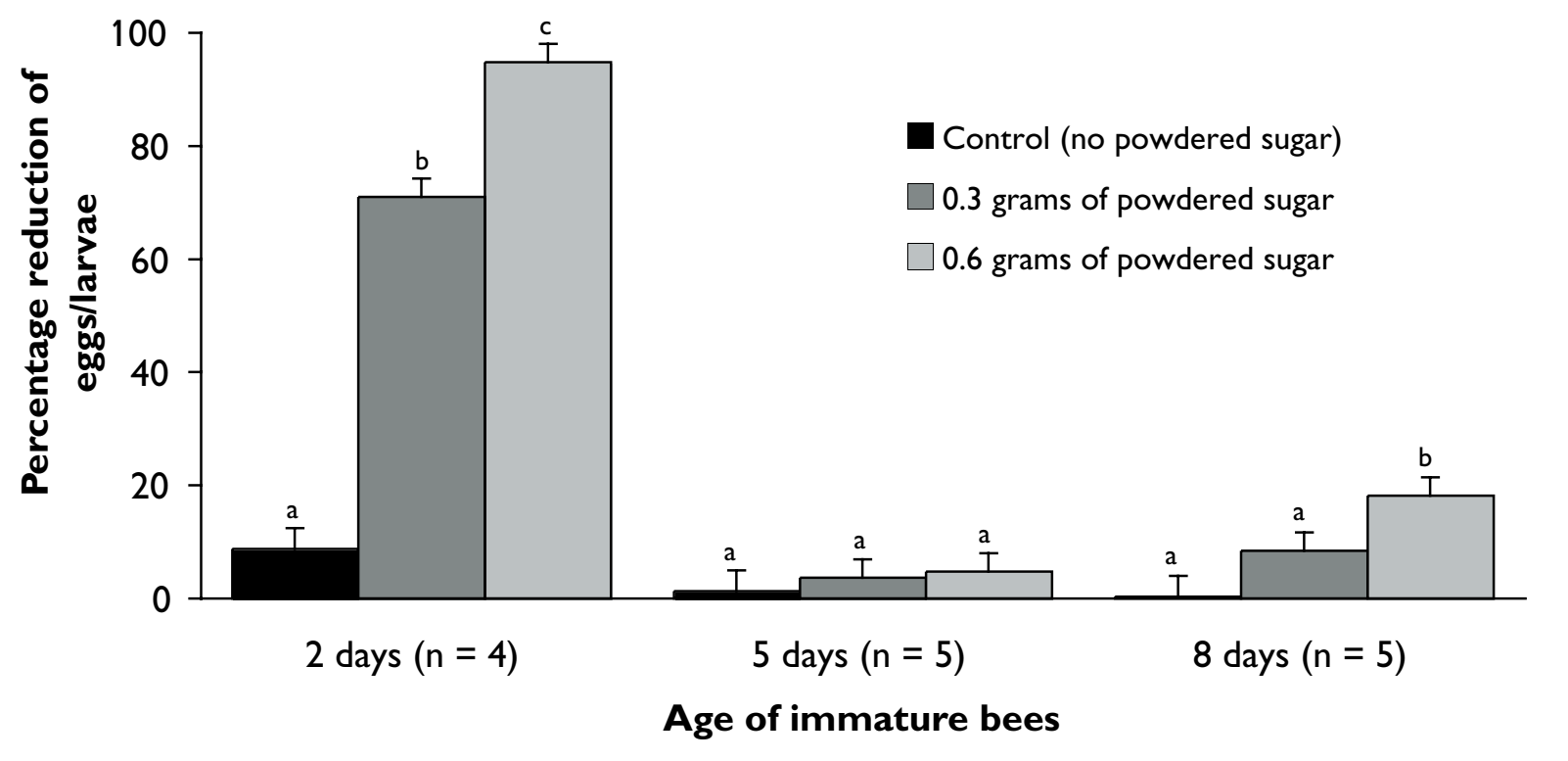

FIG. 3. The responses of 2, 5, and 8-day-old brood to dusting with three doses of powdered sugar (none, $0.3 \mathrm{~g}$, and $0.6 \mathrm{~g}$ ). Control treatments did not receive powdered sugar. Treatments bearing different letters within each age group were significantly different $(\mathrm{t}$-test,,$=0.05)$.

that $18.5 \pm 4.5 \%$ of 8 -day-old larvae were removed after dusting with the extremely high dose. We are not sure why 8- but not 5-day-old larvae were affected at the high dose, but we speculate that the sugar may have stimulated the 8-day-old larvae to move and fall from their cells.

The low dose ( $0.3 \mathrm{~g}$ per 152 cells) is closer to the actual amount of powdered sugar that could enter brood cells when applying antibiotic dusts or powdered sugar to hives without removing individual frames and applying the material directly to the brood. The low dose did not harm 5- or 8-day-old larvae but resulted in $62 \%$ egg removal. Our results indicate that doses less than or equal to $0.3 \mathrm{~g}$ per 152 brood cells will not harm larvae but may result in some egg removal.

Removal of $18.5 \pm 4.5 \%$ of 8 -day-old larvae when dusted at the high dose roughly coincides with the results described by Pettis et al. (2004). Pettis et al. applied $1 \mathrm{~g}$ of powdered sugar to 100 cells containing a mixed-age group of brood, or $1.5 \mathrm{~g}$ per 151 cells (no eggs). Although this is 2.5 -times to 5 -times our treatment rate, Pettis et al. reported that mortality (13-14\%) was not significantly different when compared with untreated brood. Similarly, Fakhimzadeh (2001) reported that powdered sugar dusting did not negatively impact capped brood or the growth of adult bee populations. Fakhimzadeh dusted colonies by blowing 10-20 g of powdered sugar between frames at 3-, 7-, and 14-day intervals. Though the actual amount of powdered sugar that entered brood cells is unknown, Fakhimzadeh's results reinforce our conclusion that powdered sugar only affects brood negatively when applied at high doses.

The results of our study suggest that brood removal following management practices that introduce powdered sugar into colonies will be restricted to eggs. The low dose tested in this study is probably greater than the amount of powdered sugar that would enter brood cells using any technique that has been described for using powdered sugar to reduce varroa populations. Actual egg removal resulting from using powdered sugar to remove mites may be negligible. The results suggest that brood removal will not limit the usefulness of powdered sugar for reducing varroa populations. We recommend, however, that beekeepers use techniques that minimize the amount of powdered sugar applied to eggs and open brood. Our technique for dusting bees in an external box carries lower risk of injuring brood than techniques that introduce powdered sugar directly into the brood nest.

\section{Acknowledgements}

Funding for this research was provided by an EPA regional PESP grant. Additional funding was provided by the Nebraska Honey Producers and the Wisconsin Beekeepers Association. We thank Cassie Callaway for her help in counting eggs and larvae. This is paper number 14643 of the journal series of the Agricultural Research Division, University of Nebraska-Lincoln.

\section{REFERENCES}

ALIANO, N P; ELLIS, MD (2004). Strategies for using powdered sugar to remove varroa mites from adult honey bees. American Bee Journal 144(5): 40-41.

FAKHIMZADEH, K (2000). Potential of super-fine ground, plain white sugar dusting as an ecological tool for the control of Varroasis in the honey bee (Apis mellifera). American Bee Journal 140(6): 487-490.

FAKHIMZADEH, K (2001). The effects of powdered sugar varroa control treatments on Apis mellifera colony development. Journal of Apicultural Research 40(3-4): 105-109.

HAYES, J (2004). The classroom. American Bee Journal 144(5): 362.

PETTIS, J S; KOCHANSKY, J; FELDLAUFER, M F (2004). Larval Apis mellifera L. (Hymenoptera: Apidae) mortality after topical application of antibiotics and dusts. Journal of Economic Entomology 97(2): 171-176.

SAS INSTITUTE (1999). SAS/STAT user's guide, version 8.0. SAS Institute; Cary, NC, USA.

SHIMANUKI, H; KNOX, D A (1994). Susceptibility of Bacillus larvae to Terramycin ${ }^{\circledast}$. American Bee Journal 134: 835 